\title{
Profitability and Determinants of Potato Yield in District Swat of Khyber Pakhtunkhwa, Pakistan
}

\author{
Salman Khan, Irfan Ullah*, Shahid Ali and Murtaza
}

Department of Agricultural and Applied Economics, The University of Agriculture, Peshawar, Khyber Pakhtunkhwa, Pakistan.

Abstract | This study identified and analyzed major determinants of potato yield in district Swat of Khyber
Pakhtunkhwa, Pakistan. A three-stage random sampling technique was used to collect data from 100
respondents during 2018. A Cobb-Douglas type production function was used to approximate effect of
determinants on potato yield. Major shares of the input cost per acre incurred in the study area were seed (Rs.
18720), followed by land rent (Rs.15890) and labors having an estimated cost of Rs. 14965 respectively. The
analysis showed that on average per acre yield of potato was recorded as $4,953.35 \mathrm{~kg}$ with net revenue of Rs.
28,261.89. The results of the Cobb-Douglas type production function revealed that the coefficients of seed,
labor, tractor, urea and chemicals were positive and statistically significant having elasticities of $0.211,0.110$,
0.103, 0.073 and 0.064, respectively. The study recommends that government should subsidize the inputs
and arrange trainings for potato growers regarding use of recommended chemical fertilizer and efficient
utilization of seed, labor and other inputs to accelerate potato production and thereby profit of farmers.
Received | January 03, 2019; Accepted | March 08, 2020; Published | July 25,2020
"Correspondence | Irfan Ullah, Department of Agricultural and Applied Economics, The University of Agriculture, Peshawar, Khyber
Pakhtunkhwa, Pakistan; Email: Irfanullah@aup.edu.pk
Citation | Khan, S., I. Ullah, S. Aliand Murtaza.2020. Profitability and determinants of potato growers in district Swat of Khyber Pakhtunkhwa,
Pakistan. Sarbad Journal of Agriculture, 36(3): 748-753.
DOI $\mid$ http://dx.doi.org/10.17582/journal.sja/2020/36.3.748.753
Keywords | Potato growers, Net revenue, Determinants of potato yield, Cobb-douglas type production function

\section{Introduction}

$\mathrm{T}$ he diverse agro-climatic conditions and fertile land in Pakistan facilitate the farming community to grow various crops including cereals, fruits, vegetables and the condiments all around the country in all the seasons. Vegetables being the short duration crop, provides the high economic return. Almost 36 types of vegetables are cultivated in Pakistan including tomato, cucumber, onion, cabbage, turnip, cauliflower, gourd, brinjal and potato etc. These vegetables are used for domestic purposes and also exported because of its taste, high nutritious value and freshness (Jan et al., 2009). The economy of people is dependent upon agriculture and mainly on potato farming (Bajracharya and Sapkota, 2017). The production and area of potatoes crop are rising day to day because of its higher demand and profitability. The annual growth rates in area of $7.14 \%$, production of $9.90 \%$ and yield of potato crop were estimated $2.76 \%$ during 1989-90 to 2008-09 (Haque et al., 2012). In the economy of Pakistan potato plays an important rule (Ahmad et al., 2005).

According to Food and Agricultural organization (2016) the global fresh potato production is estimated as 376.82 million tons on 19.246 million hectares with an average yield of 19.5 tons per ha. China is the leading potato producing country, followed by India, Russia, Ukraine and USA. Pakistan is the $19^{\text {th }}$ leading potato producing country of the world (FAO, 2016).

In Pakistan, potato is the fourth most important food crop after wheat, rice and corn. Potato is cultivated on 
an area of 0.178 million hectares, total production is about 4.00 million tons with an average yield of 22.47 tons per hectare (FAO, 2016). Punjab is the leading potato producing province in the country followed by Khyber Pakhtunkhwa, Baluchistan and Sindh (GoP, 2017).

In district Swat potato is grown in summer/autumn and contributes about $8 \%$ to the total potato production of Khyber Pakhtunkhwa. In Swat, potato is cultivated on area of 835 hectares and its production is about 10,615 tons with the average yield of 12.7 tons per hectare, which is comparatively low than yield in other districts like Chitral, Nowshera and Malakand with the yields of 30.2 , 15.63and 14.42 tons per hectare, respectively (GoP, 2017). This low yield might be due to poor production technologies, poor farming skills or poor utilization of the essential inputs.

\section{Objectives of the study}

This study was designed to estimate profitability of potato growers and analyze major determinants that affects potato yield in the study area.

\section{Materials and Methods}

This section provides detailed discussion on universe of the study, sample size and sample selection, data collection and analytical frame work.

\section{Study universe}

This study was conducted in District Swat, the third largest potato producing district of Khyber Pakhtunkhwa Province (GoP, 2017). Its geographical area is 5337 square kilometers. It is situated at $35.2227^{\circ}$ to the North and $72.4258^{\circ}$ to the East. The total population of district Swat is recorded as 2,309,570 according to the 2017 census (GoP, 2017). The agroclimate conditions and fertile lands in district Swat are quite conductive for cultivation of different fruits and vegetables.

\section{Sampling design and sample size}

A three-stage random sampling technique was used to collect data for this study. In the first stage, out of seven Tehsils in District Swat, three tehsils namely Bahrain, Khwaza-Khela and Matta were selected purposively. The main reason for the selection of these tehsil is based on the maximum numbers of potato growers. In the second stage, among the major potato producing villages, Gujjar Gabral, Miandam, and Biha-Rodingar were randomly selected. In the final stage, a random sample of 100 potato growers are selected using proportional Allocative sampling technique (Cochran, 1977) in each village as given below:

$$
n i=\frac{N i}{N} * n
$$

Where;

$\mathrm{N}$ is the total number of potato growers in the selected villages; $\mathrm{N}_{i}$ is the total number of potato growers in the ith village; $n_{i}$ is the no. of potato growers to be selected in the ith village; $n$ is the required sample of potato growers to be selected from chosen village.

\section{Data collection}

This study is based on both the primary and secondary data. Secondary data was taken from local extension department and primary data was collected from the sampled respondents at their farms and homes by using a well-designed interview schedule.

\section{Data analysis}

Net revenue: Net revenue is the difference between total value of the product and total factor cost, while total revenue is the total income of producer after selling his quantity and total cost is the sum of total variable cost and total fixed cost (Debertin, 2012; Varian, 1992). Total cost, net revenue and total revenue per acre of potato production are analyzed using the following formulas(Bajracharya and Sapkota, 2017).

$$
\begin{gathered}
\text { Net Rev }=T R-T C \ldots(2) \\
T R=P Q * Q i \quad \ldots .(3) \\
T C=P x i * X i \quad \ldots(4)
\end{gathered}
$$

Where;

$\mathrm{NR}$ is the net revenue, TC is the total cost of production, $T R$ is the total revenue, $\mathrm{P}_{\mathrm{Q}}$ is the price per unit of output, Qi is the quantity of output produced, Pxi is the price per unit of input and $\mathrm{Xi}_{\mathrm{i}}$ is the total inputs used in production process.

\section{Specification of the model}

Identification of the major determinants of potato yield is very much important to understand the response of explanatory variables to the output (Lama and Rimjim, 2017). Many of the researchers like Ahmad et al. (2005 and 2013) and Ali et al. (2017) used the Cobb-Douglas type production for 
this purpose. Seed quantity, labor working hours, tractor hours, chemical fertilizers like urea and DAP and chemicals like weedicides and pesticides are the major inputs used by potato growers in the study area (Bajracharya and Sapkota, 2017; Ahmad et al., 2005). Cobb-Douglas type production function to estimate the effect of inputs on potato yield.

Ln Yield $=\beta 0+\beta 1$ Ln Lab $+\beta 2$ Ln Tractor $+\beta 3$ Ln Urea $+\beta 4$ Ln DAP $+\beta 5$ Chemicals $+\beta 6$ Ln Seed $+e i \quad \ldots .(5)$

Where,

Ln= Natural log; Yield = Potato Yield in kgs per acre; $\beta$ 's= Parameters to be estimated; Seed = Amount of seed used in kgs per acre; Lab = Labor working hours per acre; Urea = Amount of urea fertilizer used in kgs per acre; DAP = Amount of DAP fertilizer used in kgs per acre; Tractor $=$ Tractor hours per acre; Chemicals $=$ Amount of chemicals used in bottles per acre.

\section{Diagnostic tests}

As the nature of collected data cross sectional therefore normality of error term and homoscedasticity of variance were tested by using histogram of residuals and Breusch-Pagan test, respectively.

\section{Results and Discussion}

This section presents the results from data analysis and discusses them in the light of the objectives of the study. Necessary explanations are made at appropriate places.

\section{Socio-economic characteristics of potato growers}

Age is a non-economic characteristic of the farmers having great impact on production. The age of an individual reflects the experience and attitude of the farmers. Majority (59\%) of the farmers belongs to the age group between 20 to 40 having an average age of the farmers estimated in the study area is 40.43 years with the maximum age of 55 and minimum of 28 years. The literacy rate in the study area is not so much satisfactory. Most of the farmers (64\%) are illiterate with an average level of education in the study area is recorded as 2.45 schooling years with the maximum of 18 years and minimum of no schooling. Experience regarding cultivating, harvesting, proper irrigation and technology can enhance the production. In the study area $30 \%$ of the farmers are having experience less than 10 years. The average level of farming experience in the study area is recorded as 15.5 years with the maximum and minimum of 30 and 8 years respectively. The results are given in Table 1.

Table 1: Socio-economic characteristics of potato growers.

\begin{tabular}{|c|c|c|c|c|c|}
\hline Particulars & Groups & Percentage & Mean & $\begin{array}{l}\text { Maxi- } \\
\text { mum }\end{array}$ & $\begin{array}{l}\text { Mini- } \\
\text { mum }\end{array}$ \\
\hline \multirow[t]{4}{*}{ Age } & Below 20 & ---------- & \multirow[t]{5}{*}{40.41} & \multirow[t]{5}{*}{55} & \multirow[t]{5}{*}{28} \\
\hline & $20-40$ & $59 \%$ & & & \\
\hline & $41-60$ & $41 \%$ & & & \\
\hline & Above 60 & ---------- & & & \\
\hline \multirow[t]{5}{*}{ Education } & Illiterate & $64 \%$ & & & \\
\hline & Below Matric & $28 \%$ & \multirow[t]{4}{*}{2.45} & \multirow[t]{4}{*}{18} & \multirow[t]{4}{*}{0} \\
\hline & Matric & $7 \%$ & & & \\
\hline & Graduate & $1 \%$ & & & \\
\hline & Above & --------- & & & \\
\hline \multirow{4}{*}{$\begin{array}{l}\text { Farming } \\
\text { experience }\end{array}$} & Below 10 & $30 \%$ & \multirow[t]{4}{*}{15.5} & \multirow[t]{4}{*}{30} & \multirow[t]{4}{*}{8} \\
\hline & $11-15$ & $26 \%$ & & & \\
\hline & $16-20$ & $21 \%$ & & & \\
\hline & Above 20 & $23 \%$ & & & \\
\hline
\end{tabular}

Source: Survey data, 2018

Table 2: Per acre cost of production of potato crop.

\begin{tabular}{|c|c|c|c|c|c|}
\hline Variables & Units & $\begin{array}{l}\text { Cost/Unit } \\
\text { (Rs) }\end{array}$ & $\begin{array}{l}\text { Quan- } \\
\text { tity }\end{array}$ & $\begin{array}{l}\text { Total cost } \\
\text { (Rs) }\end{array}$ & \%age \\
\hline Seeds & Kgs & 50 & 748.8 & 18,720 & 20.01 \\
\hline Tractor & Hours & 1200 & 3.37 & 4,044 & 4.32 \\
\hline Urea & Kgs & 29 & 127.25 & $3,711.25$ & 3.96 \\
\hline DAP & Kgs & 58 & 53.6 & $3,108.8$ & 3.32 \\
\hline SSP & Kgs & 22 & 38.51 & 847.22 & 0.90 \\
\hline FYM & Kgs & 3000 & 0.78 & 2,817 & 3.01 \\
\hline Chemicals & Bottles & 850 & 4.22 & $3,591.5$ & 3.83 \\
\hline Irrigation & No & $\ldots$ & 9.2 & 500 & 0.53 \\
\hline Land rent & Rs & 15890 & & 15,890 & 16.98 \\
\hline Labour hours & Hours & 400 & 38.34 & 14,965 & 15.99 \\
\hline Bags & $\ldots$. & $\ldots$. & $\ldots$ & $3,948.7$ & 4.2 \\
\hline $\begin{array}{l}\text { Total inputs } \\
\text { cost }\end{array}$ & $\ldots$ & $\ldots$ & $\ldots$ & $81,016.31$ & 86.6 \\
\hline $\begin{array}{l}\text { Loading/Un- } \\
\text { loading }\end{array}$ & $\ldots$. & $\ldots$ & $\ldots$ & 2,561 & 2.7 \\
\hline $\begin{array}{l}\text { Transporta- } \\
\text { tion }\end{array}$ & Rs & $\ldots$ & $\ldots$ & $5,617.2$ & 6.00 \\
\hline $\begin{array}{l}\text { Commission } \\
\text { charges }\end{array}$ & Rs & $\ldots$ & $\ldots$ & 694.64 & 0.74 \\
\hline $\begin{array}{l}\text { Marketing } \\
\text { cost }\end{array}$ & Rs & $\ldots$. & $\ldots$. & $12,517.04$ & 13.38 \\
\hline $\begin{array}{l}\text { Marketing + } \\
\text { inputs cost }\end{array}$ & Rs & $\ldots$. & $\ldots$. & $93,533.35$ & 100 \\
\hline
\end{tabular}

Source: Author's own estimation 2018. 
Cost of production of potato crop

The total cost incurred on the production of potato crop is the summation of fixed and variable costs. The fixed cost includes the land rent and it refers to the cost that incurred either as farmer's payment to the owner of the land or the opportunity cost of the farmer, in case if the farmer is owner of the land. The average land rent per acre in the study area is recorded Rs. 15,890 (Table 2). All the other costs are included in variable cost such as cost on inputs like seed, tractor hours, urea, DAP (Di Ammonium phosphate), FYM (Farm Yard Manure) and labor hours.

Seed is a very important input in the production of all the crops because its appropriate use ensures the level of output. The average cost on potato seed in the study area is recorded as Rs. 18,720/acre. Tractor cost includes the cost on deep ploughing, levelling, planking and clot breaking. The average cost incurred on tractor hours in the study area is Rs. 4,044 per acre. Labor is considered as an important input being involved in different activities from the very early stage of production process till the crop is harvested. In potato production labor cost includes all the physical activities of ridge making, fertilization and chemical application, irrigation, picking and packing of the final product. The per acre average cost of labor in the study area is recorded as Rs. 14,965 per acre. FYM is easily available to the farmers and quite affective in enhancing soil fertility. The average cost incurred on FYM is Rs. 2,817 per acre. Fertilizer cost include the cost incurred on chemical fertilizers such as DAP, Urea and SSP. The average per acre cost incurred on DAP, Urea and SSP is recorded as Rs. 3,108.8, Rs. 3,711.25 and Rs.847.22, respectively. Chemicals like pesticides and weedicides etc. are as much important as the fertilizers. The average cost on chemicals is Rs. 3,591.5 per acre. The annual water charges for potato crop is 500 per acre. Marketing cost is the summation of costs incurred on bags, loading transportation, commission and unloading. The total average marketing cost is recorded as Rs.12, 517.04.

\section{Total revenue}

Total revenue is obtained by the product of total quantity produced and prevailing market price. The total production per acre in the study area is 4,953.35 kgs and price per $\mathrm{kg}$ is Rs.22. Thus, total revenue of the potato growers in the study area is Rs. 1,08,973.7.
Net revenue

Net revenue is obtained by subtracting the total cost from the total revenue. The profitability ratio for potato crop is 0.35 , showing that one-rupee investment on potato crop would generate profit of 0.35 rupees (Table 3 ).

Table 3: Total cost, gross and net revenue (per acre).

\begin{tabular}{|c|c|c|c|c|c|}
\hline Particulars & Unit & $\begin{array}{l}\text { Quan- } \\
\text { tity }\end{array}$ & $\begin{array}{l}\text { Price/ } \\
\text { kg (Rs) }\end{array}$ & Value(Rs) & $\begin{array}{l}\text { Profitabil- } \\
\text { ity ratio }\end{array}$ \\
\hline Main product & $\mathrm{Kg}$ & 4953.35 & 22 & 108973.7 & \multirow{4}{*}{$\begin{array}{l}=\mathrm{NR} / \mathrm{TC} \\
=0.35\end{array}$} \\
\hline Gross revenue & & & & 108973.7 & \\
\hline Total cost & $\ldots$ & $\ldots \ldots$. & $\ldots \ldots$. & 80711.81 & \\
\hline Net revenue & .... & ....... & ........ & 28261.89 & \\
\hline
\end{tabular}

Source: Author's own estimation (2018).

Per acre net revenue of potato growers

$$
\begin{gathered}
\pi=T R-T C \\
=P_{Q}{ }^{*} Q i-P x i{ }^{*} X i \\
=108973.7-80711.81 \\
\pi=28261.89(P K R)
\end{gathered}
$$

\section{Cost and revenue comparison among tebsils}

The results in Table 4 reveal that the average net revenue in tehsil Khwaza-khela is Rs. 28462.45, higher among all the chosen tehsils followed by Matta and Bahrain with the net revenues of Rs. 28189.9 and Rs.28141.38, respectively. The average production in tehsil Bahrain is recorded as4975.676 kgs, highest among all the three tehsils followed by tehsil Khwaza-khela and tehsil Matta with the production of $4945 \mathrm{kgs}$ and $4935 \mathrm{kgs}$, respectively. The average gross revenue estimated for tehsils Bahrain, Khwazakhela and Matta are Rs. 109464.9, Rs.108790 and Rs.108570, respectively. The profitability ratios for potato crop in tehsils Bahrain, Khwaza-khela and Matta are 0.34, 0.35 and 0.35, respectively, showing that one-rupee investment on potato crop would generate profit of Rs.0.34, Rs.0.35 and Rs.0.35 in these tehsils respectively.

Table 4: Cost and revenue comparison among tehsils.

\begin{tabular}{lllll} 
Tehsils & \multicolumn{2}{c}{$\begin{array}{l}\text { Cost of } \\
\text { production }\end{array}$} & \multicolumn{1}{c}{ Gross } & \multicolumn{2}{l}{$\begin{array}{l}\text { Net reve- } \\
\text { nue }\end{array}$} & $\begin{array}{l}\text { Profitability } \\
\text { ratio }\end{array}$ \\
Bahrain & 81323.49 & 109464.9 & 28141.38 & 0.34 \\
Khwaza-khela & 80327.55 & 108790 & 28462.45 & 0.35 \\
Matta & 80380.10 & 108570 & 28189.9 & 0.35
\end{tabular}

Source: Author's own estimation (2018).

Results of Cobb-Douglas type production model

Results of Cobb-Douglas type production function 
(Table 5) reveals that all the explanatory variables are positive and statistically significant at 5\% level, except DAP. The coefficient of DAP is positive but highly insignificant that might be due to the partial application of the input. A one percent increase in the seed quantity and labor working hours will increase yield of potato by $0.21 \%$ and $0.11 \%$, respectively, which is highest among all the explanatory variables. These results are consistent with Abedullah et al. (2006), who also found a positive coefficient for seed and labor hour for potato crop. This implies that these inputs are playing a major role in potato production. The coefficients of tractor hours, chemicals (weedicides and pesticides) and urea showed that one percent change in these variables will increase potato yield by $0.10 \%, 0.06 \%$ and $0.07 \%$, respectively. These results are in line with the findings of Ahmad et al. (2013), found positive coefficient of seed and fertilizer for potato crop in Rangpur District of Bangladesh. The results show that a $1 \%$ increase in chemical and tractor hours, will increase yield by $0.064 \%$ and $0.10 \%$. The $\mathrm{p}$-value for F-statistic show that overall the model is significant and the value of $\mathrm{R}^{2}$ shows $96 \%$ variation in the output is explained by variation in explanatory variables included in model (5).

\section{Diagnostic tests}

Normality: The problem of normality was checked through histogram which showed that the data is normally distributed.

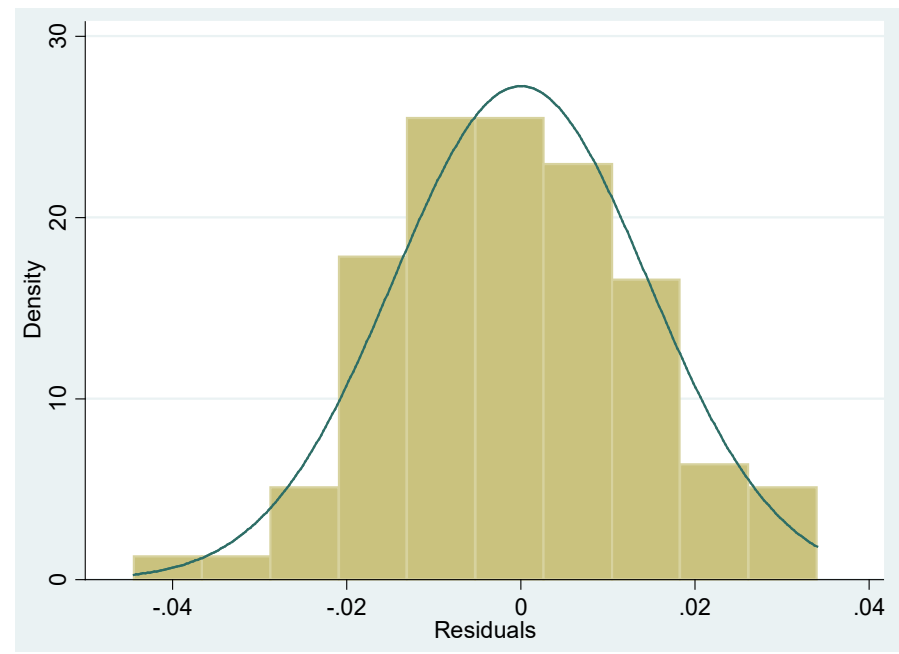

\section{Homoscedasticity}

One of the assumption of the classical linear regression model is that the variance should be the same and if this assumption is violated then we face the problem of heteroscedasticity. For this purpose, Breusch-Pagan test was carried out and the results having $\mathrm{p}$-value greater than 0.05 revealed that the data is free from heteroscedasticity. The problem of normality was checked through histogram which showed that the data is normally distributed.

Table 5: Results of Cobb-Douglas type production model.

$\begin{array}{lllll}\text { Variables } & \text { Coefficients } & \text { Std. Error } & \text { t-statistic } & \text { P-value } \\ \text { LnSeed } & .211 & .045 & 4.61^{* *} & 0.000 \\ \text { LnUrea } & .073 & .013 & 5.41^{* *} & 0.000 \\ \text { LnDAP } & .004 & .009 & 0.53^{\text {ns }} & 0.595 \\ \text { LnChemicals } & .064 & .016 & 3.84^{* *} & 0.000 \\ \text { LnTractor } & .103 & .016 & 6.37^{* *} & 0.000 \\ \text { LnLab } & .110 & .041 & 2.70^{* *} & 0.002 \\ \text { Constant } & 6.54 & .266 & 24.5 & 0.000\end{array}$

Overall model significance

F-statistic (427.97) P-value (0.000)

$\mathrm{R}$-squared

0.965

Source: Author's own estimation (2018).

** Statistically significant at $1 \%$.

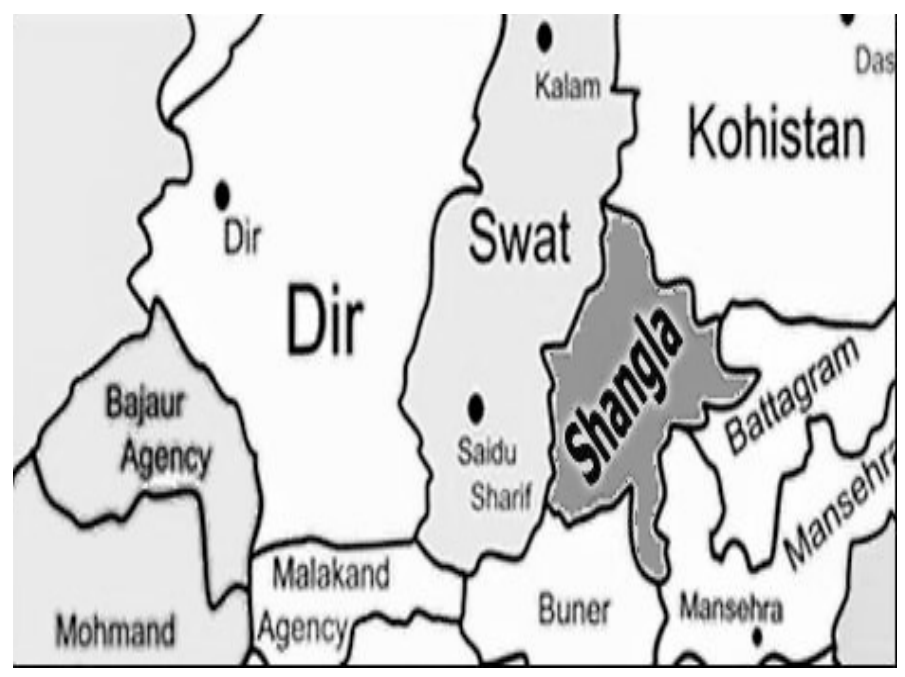

Figure 1: District Swat location.

Source: Pakimag.com

\section{Conclusions and Recommendations}

The results of this study show that literacy rate in the study area is not so much satisfactory while the sampled respondents in the study area are having high farming experience in cultivation of potato. The highest cost incurred on potato production is in tehsil Bahrain followed by tehsil Matta and tehsil Khwazakhela, respectively. The average net revenue in tehsil Khwaza-khela is highest followed by tehsil Matta and tehsil Bahrain. Results of the Cobb-Douglas type production function reveal that all explanatory variables are highly significant, having positive effect on potato yield except DAP. Explanatory variables 
such as seed, labor and tractor use showed positive and significant effect on potato production. The summation of all the coefficients of the regressors show that the sample respondents in the study area are operating in the second stage of the production. This study recommends that potato growers need to increase the application of seed, labor and tractor hours to increase potato yield. Extension department should arrange training programs for potato growers in the study area to sensitize them about the application of recommended dose of inputs involved in the potato production process. Formal and informal credit facilities should be provided to the farmers on easy term and conditions for the purchase of costly inputs such as seed, DAP, urea and weedicide. Similar studies should also be carried out in other major potato producing districts of the province for the estimation of productivity and profitability of potato growers.

\section{Novelty Statement}

This study employed Cobb-Douglas type production function to approximate the effects of determinants on potato yield in Swat district of Khyber Pakhtunkhwa. Results suggested that increase in application of seed, labor and tractor hours will boost up potato yield in the study area.

\section{Author's Contribution}

Salman Khan carried out the study, reviewed literature, collected data and wrote first draft of the manuscript. Irfan Ullah developed main theme of the study, helped in writing abstract, introduction and references. Shahid Ali helped in writing materials and methods, model specification and analysis. Murtaza interpreted results, helped in writing, conclusions, recommendations and references. All authors read and approved the final manuscript.

\section{Conflict of interest}

The authors have declared no conflict of interest.

\section{References}

Abedullah, K., Baksh, and B. Ahmad. 2006. Technical efficiency and its determinants in potato production, evidence from https:// doi.org/10.35536/lje.2006.v11.i2.a1 Punjab, Pakistan. Lahore J. Econ. 11(2): 1-22.

Ahmad, B., K. Bakhsh, S. Hassan and W. Ahmad. 2005. Profitability and various constraints in potato cultivation. Pak. J. Agric. Sci. 42(3): 6873.

Ahmed, M.A.Z., R.S. Johir and H. Masudul. 2013. Farmer profitability of potato cultivation at Rangpur district. The socio-economic context of Bangladesh. Russ. J. Agric. Socio-Econ. Sci. 19(7): 136-144.

Ali, Q.,M.Ashfaq and M. Khan.2017. An economic analysis of off-season tomato production in Punjab. J. Anim. Plant Sci. 27(1): 294-301.

Bajracharya, M. and M. Sapkota. 2017. Profitability and productivity of potato (Solanum tuberosum) in Baglung district, Nepal. Agric. Food Secur. 6(1): 17-125. https://doi.org/10.1186/s40066017-0125-5

Cochran, W.G., 1977. Sampling techniques, $3^{\text {rd }}$ Edition. John Wiley and Sons, New York. pp. 37-45.

Debertin, D.L., 2012. Agriculture production economics, $2^{\text {nd }}$ Edition. MacMillan Publishing, a division of MacMillan Inc. N.J. USA.

Food and Agriculture Organization (FAO). 2016. Year wise world Potato Statistics, https://www. potatopro.com/world/potato-statistics.

GoP. 2017. Agricultural statistics of Pakistan, 201617. Ministry of food, agriculture and livestock. Econ. Wing, Islamabad, Pakistan.

Haque, M.A., M.M. Miah, S. Hossain and M.M. Rahman. 2012. Profitability of bari released potato verities in some selected locations of Bangladesh. Bangladesh J. Agric. Res. 37(1): 149-158. https://doi.org/10.3329/bjar. v37i1.11189

Jan, A., A. Sadiqa, D. Jan, R. Khan, G. Ali, M. Fayaz and M. Khan. 2009. Estimating the differences in profitability of selected vegetables: A dummy variable approach. Sarhad J. Agric. 25(4): 587589.

Lama,M.and R.Bordoloi.2017.Potato Productivity and its determinants: A case study in Sonitpur District, Assam. Soc. Change Dev. pp. 12.

Varian, H.R., 1992. Microeconomic analysis, third edition, Univ. Michigan, New York, London. 